\title{
VPLYV PRIJATIA NOVÉHO ZÁKONA O OCHRANE SPOTREBITELA NA POSTAVENIE SPOTREBITELA NA TRHU ELEKTRONICKÝCH KOMUNIKÁCIÍ
}

\author{
Margita Majerčáková ${ }^{1}$
}

\section{Úvod}

Základným právnym predpisom v oblasti ochrany spotrebitel'a je zákon o ochrane spotrebitel'a. Každá oblast' národného hospodárstva má však ešte svoje vlastné právne predpisy upravujúce ochranu spotrebitel'a na konkrétnom trhu. Oblast' elektronických komunikácí́ je upravená príslušnými právnymi predpismi, za prípravu a uplatňovanie ktorých je zodpovedné Ministerstvo dopravy, pôšt a telekomunikácií.

\section{Prínosy nového zákona}

Zákon o ochrane spotrebitel'a, ktorý bol prijatý ešte v roku 1992 (Zákon č. 634/1992 Z. z.) [3] bol v čase jeho platnosti desat' krát novelizovaný. Týmito zmenami sa skomplikovalo jeho používanie širokým okruhom spotrebitel'ov, ale aj štátnych orgánov, ktoré na jeho základe vykonávajú kontrolu. Ďalším dôvodom prijatia nového zákona bol nový prístup k jeho celkovej koncepcii. Následne bol vypracovaný nový zákon, ktorý bol koncipovaný ako všeobecný a konkrétnosti boli riešené $\mathrm{v}$ jednotlivých nariadeniach vlády. Táto koncepcia je výhodnejšia najmä $\mathrm{z}$ dôvodu, že smernice Európskej únie $\mathrm{v}$ tejto oblasti podliehajú zmenám $\mathrm{z}$ hl'adiska zistenia nových prístupov $\mathrm{k}$ ešte dôkladnejšej ochrane práv spotrebitel'a vo vzt'ahu $\mathrm{k}$ bezpečnosti výrobkov a služieb. V budúcnosti by malo dôjst' pri zmenách smerníc len $\mathrm{k}$ novele aproximačných nariadení vlády a nie ku vstupovaniu do zákona niekol'kokrát ročne. Za týchto podmienok bol prijatý zákon č. 250/2007 Z. Z. o ochrane spotrebitel'a a o zmene zákona Slovenskej národnej rady č. 372/1990 Z. z. o priestupkoch $\mathrm{v}$ znení neskorších predpisov [2]. V čase jeho zverejnenie neboli však známe všetky jeho dopady na vzt'ah podnikatel' - spotrebitel', čo spôsobilo znovu otvorenie tejto problematiky. Výsledkom bolo prijatie súčasného zákona č. 397/2008 Z. z., ktorým sa mení a doplńa zákon č. 250/2007 Z. z. o ochrane spotrebitel’a a o zmene zákona Slovenskej národnej rady č. 372/1990 Z. z. o priestupkoch v znení neskorších predpisov a o zmene a doplnení niektorých zákonov.

Ciel'om prijatia bolo hlavne odstránenie niektorých nedostatkov $\mathrm{v}$ texte zákona a úprava kompetencií orgánov štátnej správy. Zákon okrem legislatívno-technických nesprávností rieši aj konkretizáciu práv a povinností vo vzt'ahu podnikatel' - spotrebitel', odstraňuje neprimerané zat'aženie predávajúceho pri vybavovaní reklamácií, upravuje pôsobnosti správneho poriadku vo vzt’ahu k právnym vzt'ahom upraveným týmto zákonom. oblasti:

Nový zákon okrem legislatívno-technických nesprávností rieši aj tieto základné

\footnotetext{
${ }^{1}$ Dr. Ing. Margita Majerčáková, Katedra spojov, Fakulta prevádzky a ekonomiky dopravy a spojov, Žilinská univerzita v Žiline, Univerzitná 1, 01026 Žilina, Slovenská republika, tel.: +421415133126, fax: +421415655615 e-mail: Margita.Majercakova@ fpedas.uniza.sk
} 
- konkretizuje práva a povinnosti vo vzt'ahu podnikatel' - spotrebitel',

- odstraňuje nedostatky implementácie smernice Európskeho parlamentu a Rady 2001/95/ES z 3.12.2001 o všeobecnej bezpečnosti výrobkov,

- implementuje smernice Rady 2004/113/ES z 13.12.2004 o vykonávaní zásady rovnakého zaobchádzania medzi mužmi a ženami $\mathrm{v}$ prístupe $\mathrm{k}$ tovaru a službám a k ich poskytovaniu na spotrebitel'ské právne vzt'ahy,

- odstránenie neprimeraného zat’aženia predávajúceho pri vybavovaní reklamácí́,

- úprava pôsobnosti správneho poriadku vo vzt’ahu k právnym vzt’ahom upraveným týmto zákonom.

\section{Zmeny v novom zákone}

Oproti predchádzajúcemu zákonu nastali hlavné zmeny z dôvodu preberania smernice Európskeho parlamentu a Rady 98/6/ES zo 16.februára 1998 o ochrane spotrebitel'a pri označovaní cien výrobkov ponúkaných spotrebitel'ovi.

Znenie $\$ 2$ oproti predošlému stavu bolo doplnené o definovanie predajnej ceny: „,predajnou cenou konečná cena vrátane dane z pridanej hodnoty a v̌̌etkých ostatných daní za jednotku výrobku alebo za určené množstvo výrobku "[1].

$\mathrm{V} \S 3$ nastala zmena $\mathrm{v}$ definovaní práv spotrebitel'a na výrobky a služby v dobrej kvalite na výrobky a služby v bežnej kvalite. $\$ 3$ bol doplnený odsekom 6: „,Každý spotrebitel' má právo na zvýšenú ochranu svojich ekonomických záujmov v procese zavedenia meny euro $v$ Slovenskej republike. Spotrebitel' má právo najmä na informácie o cenách zároveñ $v$ slovenskej mene a tiež v eurách podl'a osobitných predpisov a na výrobky a služby za ceny, ktoré nie sú zvýšené z dôvodu nákladov a výdavkov súvisiacich so zavedením meny euro. " [1]

Povinnosti predávajúceho $\mathrm{v} \$ 4$ boli doplnené o poskytnutie potrebnej súčinnosti Európskemu spotrebitel'skému centru pri riešení sporu medzi spotrebitel'om a predávajúcim pri vybavovaní cezhraničnej reklamácie. Zároveň bola spresnená povinnost' predávajúceho o dodržiavaní rovnakého zaobchádzania v poskytovaní výrobkov a služieb a definovaná výnimka v podmienkach viazanosti predaja:

- ak predávajúci predáva tieto výrobky alebo poskytuje tieto služby aj samostatne,

- ak viazanie predaja je podmienené technickou nemožnost’ou samostatného predaja výrobkov alebo poskytovania služieb.

Prijatie zákona prinieslo aj zovšeobecnenie zistenia, že výrobok, ktorý bol uvedený na trh je nebezpečný nielen na základe informácií, ktoré zistili odborníci ale aj na základe zistení výrobcu, predávajúceho, dovozcu alebo dodávatel'a. Zákon im ukladá povinnost' ohlásit' to orgánu dozoru a uviest' informácie o opatreniach, ktoré prijali alebo ktoré treba prijat' na zabránenie ohrozeniu spotrebitel'a.

Z hl'adiska informačných povinnosti došlo k zmene, že ak svoju povinnost' nesplní výrobca je ju povinný doplnit' dovozca alebo dodávatel'. Výrobok však nesmie zostat' bez informačných údajov o vlastnostiach dodaného výrobku a taktiež nesmie dochádzat' k pozmeňovaniu informácií medzi výrobcom, dovozcom a dodávatel’om.

Pri označovaní výrobkov cenami nie je potrebné označit' výrobok cenami ak je výrobok poskytovaný ako súčast' služby.

Z ohl'adom na zavedenie meny euro v Slovenskej republike je predávajúci povinný počas obdobia duálneho zobrazovania cien, platieb a iných hodnôt predávané výrobky a ponúkané služby označit' cenami zároveň $\mathrm{v}$ slovenskej mene a tiež $\mathrm{v}$ eurách podla osobitných predpisov. Zároveň predávajúci nesmie zvyšovat' ceny za predávané výrobky a ponúkané služby z dôvodu nákladov a výdavkov súvisiacich so zavedením meny euro a je povinný zaokrúhl'ovat' ceny pri duálnom zobrazovaní podl'a pravidiel osobitného predpisu. 
Zmena sa týka aj elektronických zobrazovacích zariadení pri poskytovaní elektronických komunikačných služieb a pri predaji tovaru alebo poskytovaní služieb prostredníctvom elektronických prostriedkov dial'kovej komunikácie, kde možno aj po prechode na euro najdlhšie však do skončenia obdobia duálneho hotovostného peňažného obehu zobrazovat' namiesto ceny tovaru alebo služby $\mathrm{v}$ eurách len informatívnu peňažnú sumu v slovenských korunách, ak táto cena nepodlieha duálnemu zobrazovaniu alebo je vyňatá $\mathrm{z}$ duálneho zobrazovania, ak skoršie zobrazovanie tejto ceny v eurách preukázatel'ne nie je možné z technických dôvodov a ak tento zákon alebo osobitný predpis neustanovuje inak.

V reklamačnom poriadku nastali zmeny týkajúce sa plynutia reklamačnej lehoty na dve 12 mesačné obdobia. Ak spotrebitel' reklamáciu výrobku uplatnil počas prvých 12 mesiacov od kúpy, môže predávajúci vybavit’ reklamáciu zamietnutím len na základe odborného posúdenia (bez ohl'adu na výsledok odborného posúdenia nemožno od spotrebitel'a vyžadovat' úhradu nákladov na odborné posúdenie ani iné náklady súvisiace s odborným posúdením). Ak spotrebitel' reklamáciu výrobku uplatnil po 12 mesiacoch od kúpy a predávajúci ju zamietol, osoba, ktorá reklamáciu vybavila, je povinná v doklade o vybavení reklamácie uviest', komu môže spotrebitel' zaslat' výrobok na odborné posúdenie (ak je výrobok zaslaný na odborné posúdenie určenej osobe, náklady odborného posúdenia, ako aj všetky ostatné s tým súvisiace účelne vynaložené náklady znáša predávajúci bez ohl’adu na výsledok odborného posúdenia) Ak spotrebitel' odborným posúdením preukáže zodpovednost' predávajúceho za vadu, môže reklamáciu uplatnit' znova; počas vykonávania odborného posúdenia záručná doba neplynie. Predávajúci je povinný spotrebitel'ovi uhradit' do 14 dní odo dňa znova uplatnenia reklamácie všetky náklady vynaložené na odborné posúdenie, ako aj všetky s tým súvisiace účelne vynaložené náklady. Znova uplatnenú reklamáciu nemožno zamietnut'.

\section{Záver}

Prijatie tohto zákona má pozitívny vplyv na širokú verejnost' z hl'adiska prístupu $\mathrm{k}$ ochrane ich práv ako spotrebitel'ov a je v súlade so Smernicou EP a Rady 98/27/ES z 19. mája 1998 o súdnych príkazoch na ochranu spotrebitel'ských záujmov. Zákon presnejšie a rozsiahlejšie vymedzuje pojmy používané $\mathrm{v}$ zákone, aby nedochádzalo $\mathrm{k}$ ich deformácií. Zároveň rieši:

- jednoznačnú špecifikáciu práv spotrebitel'a,

- splnenie kritérií výrobkov a služieb zo strany predávajúceho tak, aby sa dostali ku spotrebitel'ovi bez následných komplikácií,

- zákaz nekalých obchodných praktik

- zákaz diskriminácie, rovnakého prístupu podnikatel'a ku všetkým spotrebitel’om pri poskytovaní výrobkov a služieb,

- otázku spôsobu rezervácie výrobkov a služieb, prípadne označenie už predaných výrobkov, ktoré sa nachádzajú v obchodnej sieti

- zákaz klamania spotrebitel'a

- zákaz ponuky a predaja nebezpečných výrobkov, zároveň riešenie otázky stiahnutia výrobkov z trhu a predovšetkým povinnost' informovat' spotrebitel'a o zistení, že výrobok je nebezpečný,

- povinnost' poskytnutia informácií predávajúcim, vrátane predvedenia výrobku, dôraz je predovšetkým položený na správny opis rizík, ktoré výrobok alebo poskytovaná služba môže spôsobit',

- označovanie výrobku alebo služby všetkými potrebnými údajmi, ktoré spotrebitel' potrebuje z hl'adiska výberu výrobku alebo služby, spôsob predávania použitých výrobkov, ktoré sa vždy musia predávat' oddelene od ostatných a musia byt' primerane označené,

- povinnost' označenia výrobku alebo služby cenou, 
- možnosti reklamácie, prípadne možnosti záručnej opravy, povinnosti informovat' o podmienkach a spôsobe uplatnenia tohto práva pre spotrebitel'a.

Z hl'adiska postavenia spotrebitel'a na trhu elektronických komunikácií sa tieto zmeny premietnu do zákona o elektronických komunikáciách, kde je definovaný koncový užívatel' ako spotrebitel' a zároveň do všeobecných podmienok poskytovania elektronických komunikačných služieb jednotlivých operátorov, ktoré nesmú byt' v rozpore so zákonom o ochrane spotrebitel'a.

\section{Literatúra}

[1] Zákon 397/2008, ktorým sa mení a dopĺn̆a zákon č. 250/2007 Z. z. o ochrane spotrebitel’a a o zmene zákona Slovenskej národnej rady č. 372/1990 Zb. o priestupkoch v znení neskorších predpisov a o zmene a doplnení niektorých zákonov [Online]. [s.a.].[Citované 2009-1-12] Dostupné na:

http://www.zbierka.sk/zz/predpisy/default.aspx?PredpisID=208427\&FileName=zz200800397-0208427\&Rocnik=2008

[2] Zákon 250/2007 o ochrane spotrebitel’a a o zmene zákona Slovenskej národnej rady č. 372/1990 Zb. o priestupkoch v znení neskorších predpisov [Online]. [s.a.].[Citované 2009-1-12] Dostupné: http://www.zbierka.sk/zz/predpisy/default.aspx?PredpisID=207482\&FileName=zz0700250-0207482\&Rocnik=2007

[3] Zákon 634/1992 o ochrane spotrebitel'a [Online]. [s.a.].[Citované 2009-1-12] Dostupné: http://www.strategie.sk/files/dokumenty/zakony/Ochrana_spotrebitela.pdf

\section{Grantová podpora}

- VEGA 1/0468/08 Inovačné stratégie v sektore služieb 